\title{
Acts of Writing: A Compilation of Six Models that Define the Processes of Writing
}

\section{Laurie A. Sharp}

Asst. Prof., John G. O'Brien Distinguished Chair in Education, Department of Education, West Texas A\&M University, Canyon, TX, USA, lsharp@wtamu.edu

Writing is a developmental and flexible process. Using a prescribed process for acts of writing during instruction does not take into account individual differences of writers and generates writing instruction that is narrow, rigid, and inflexible. Preservice teachers receive limited training with theory and pedagogy for writing, which potentially leads to poor pedagogical practices with writing instruction among practicing teachers. The purpose of this article was to provide teacher educators, preservice teachers and practicing teachers of writing with a knowledge base of historical research and models that define and describe processes involved during the acts of writing.

Key Words: writing, writing instruction, models of writing, teachers, writing process

\section{INTRODUCTION}

According to Dyson and Freedman (2003), “. . . writing is a developmental process” (p. 967). A lot of research and literature have attempted to formulate a model that describes the processes during the acts of writing (e.g., Emig, 1967, 1971; Flower \& Hayes, 1981; Graves, 1983, 1994; Hayes \& Flower, 1980, 1986; Murray, 1968; Rohman, 1964; Zoellner, 1969). However, Dyson and Freedman noted that ". . . there is no "writing process,' but a flexible process, one influenced by the kind of writing being attempted, the writer's purpose and the situational conditions" (p. 974). Teachers of writing typically implement a process approach during writing instruction that prescribes the successive use of specific processes of planning, drafting, revising, editing and publishing during the acts of writing (Lacina \& Silva, 2011). Although this model for the acts of writing has been described as "recursive" (p. 133), it is often applied as a prescribed, linear process within the context of the classroom. This narrow perspective towards the acts of writing disregards the theoretical understandings that (a) writing is developmental and (b) the processes that a writer uses during the acts of writing are flexible. Thus, teachers of writing potentially lack an understanding for the various processes at work during the acts of writing among each student writer, and writing instruction potentially becomes narrow, rigid and inflexible. Murray (1985) noted that the processes associated with the acts of writing vary with each writing task and should take into consideration each writer's personality, cognitive style and experiences. 
With the aforementioned process model of writing being a popular instructional method during the teaching of writing, one might inquire as to its effectiveness. Numerous studies have reported positive effects with certain groups of students' writings when the process approach to writing was a part of the writing instruction (e.g., Graham, McKeown, Kiuhara \& Harris, 2012; Graham, \& Perin, 2007; Graham \& Sandmel, 2011). On the other hand, Gillespie, Olinghouse and Graham (2013) reported findings that revealed "a relatively nuanced but also generally unsophisticated understanding of the process of writing" (p. 583) among fifth-grade student writers. Applebee and Langer (2011) reported that significant attention was given to process-oriented writing in secondary classrooms, but Baines, Baines, Kunkel and Stanley (1999) argued that a focus upon a prescribed process for writing instead the enhancement of students' writings loses "the art and soul of writing" (p. 72).

It is important to note that a process-oriented approach during writing is not without value during the teaching of writing. On the contrary, many well-respected researchers within the field of education have shown that a writer and a piece of writing go through several different processes from the initial thought to the final written composition. However, the research has also shown that preservice teachers receive a limited training with theory and pedagogy for writing (Norman \& Spencer, 2005) and are often anxious and lack confidence in their ability to teach writing due to limited knowledge and experiences (Grisham \& Wolsey, 2011). The lack of preparation to teach writing among preservice teachers' potentially leads to poor pedagogical practices with writing instruction among practicing teachers (Spear-Swerling \& Zibulsky, 2014). Therefore, the aim of this article was to describe six well-known models that define the processes of writing to build the pedagogical understanding about the acts of writing among teacher educators, preservice teachers and practicing teachers of writing.

\section{METHOD}

Prior to consulting available literature on the processes of writing, the following criteria were used to identify the inclusion of literature in this analysis: (a) be written in English, (b) include analyses of writers of all ages, and (c) explore and identify the specific processes that occur during acts of writing from beginning to end. As an initial exploration, parameters for dates of publication, type of analyses conducted (i.e., quantitative, qualitative, or mixed methods), or type of publication (i.e., peer-reviewed journal, dissertation, independent publication) were not established. The initial search strategy was to search the Academic Search Complete database, which accessed over 9,300 journals, as well as monographs, reports, conference proceedings, and other publications. During this search, various combinations of keywords were used, including writing, composition, writing process, and writing stages, as well as keywords that described specific stages of writing, such as prewriting, drafting, and revising. Although the database search yielded myriad of results, publications that defined the specific processes that a writer uses while producing a piece of writing were focused upon. Once the database search was exhausted, an ancestry search was conducted with pertinent publications that involved reviewing relevant citations.

The search strategies utilized identified six primary models that described the processes that occur during acts of writing. The models selected spanned approximately 20 years 
and were mindful to include scholars of seminal works. In the following literature review, these models are presented in a chronological order and include a description of the respective writing processes. An evaluation of the models was not provided; rather, they are presented as data analysis results to achieve the purpose of this article.

\section{LITERATURE REVIEW}

D. Gordon Rohman and Albert O. Wlecke: Stages of Writing - Prewriting, Writing, and Rewriting

Rohman and Wlecke (1964) analogized the act of writing with a growth of a plant due to the different stages involved with the "growth' of a writing idea from thoughts and sensations into words on paper" (p. 12). Rohman and Wlecke designated all activity that takes place before a script appears on a paper as prewriting, while all activity that takes place once written words are placed on paper as either writing or rewriting. Much of Rohman and Wlecke's research focused upon the prewriting stage because they believed that the activity that takes place during this time was the most critical part of the writing process.

Rohman and Wlecke (1964) referred to prewriting as "the stage of discovery" (p. 16) and drew the following conclusions:

- Discovery thought processes were very different from remembering thought processes during prewriting. Discovery is the beginning of a new idea, whereas remembering is merely a recollection of ideas stored in memory.

- Discovery thought processes were very similar to cause and effect scenarios. Written ideas grow and evolve from preceding written ideas.

- Good writing was dependent upon productive discovering thought processes.

- Although discovering thought processes might not have always lead to good writing, remembering thought processes will never produce good writing.

- Effective writing instruction required explicit distinction between discovering thought processes and the act of writing. In other words, student writers must experience writing instruction that extends beyond the identification of good examples of writing. Student writers must learn about the efforts required to produce good writing.

- Writers required more than mere knowledge of standards for good writing.

- Writers learned from experience.

Rohman and Wlecke (1964) also acknowledged that the writer was a crucial part of the writing process and touted the importance of providing writers "real involvement" in the acts of writing (p. 22). Rohman and Wlecke suggested effective discovering thought processes that involved the writer with writing during the prewriting stage included the use of journal writing, application of meditation principles and analogizing present experiences with past occurrences.

\section{Janet Emig: Composition Processes among Twelfth Grade Students}

Emig's $(1967,1971)$ works have become some of the most influential studies within the field of composition because she presented a different focal point with respect to writing. Emig (1967) called into question the "monolithic" (p. 130) writing process that 
consisted of the three components of planning, writing and revising, which followed a "lockstep, nonrecursive left-to-right sequence" (p. 131). Emig hypothesized that the act of writing had a potential to include more or fewer than these three components and was a "recursive" act, as opposed to a linear sequence (p. 131).

Emig's (1971) dissertation research explored the composition processes among student writers. Emig conducted eight case studies with twelfth grade students enrolled in a public high school in the United States and operationalized ten dimensions of the recursive composing process with which to analyze data from each case study (see Figure 1). Emig presented these dimensions in an outline format before the analysis of data occurred to establish a category system (see Table 1). Emig's (1971) results revealed that writing experienced by these high school students was "a limited, and limiting, experience" (p. 97). With regard to the process of composing, Emig noted an absence of attention to prewriting, including the provision of time and quiet spaces "for certain kinds of encounters with words and concepts" (p. 99). Emig's results also showed that the act of revision was obsolete because there was not enough time designated for significant "reformulation or reconceptualization" (p. 99) to occur. Emig (1983) later proclaimed that all forms of writing progress through the following three basic stages:

- The Subject Stage - The writer selects and narrows a writing topic and collects the materials needed for the writing task.

- The Preparation Stage - The writer then organizes their materials and outlines their ideas.

- The Writing Stage - The writer engages with the actual writing, which includes initial drafting, revising and a written final draft.

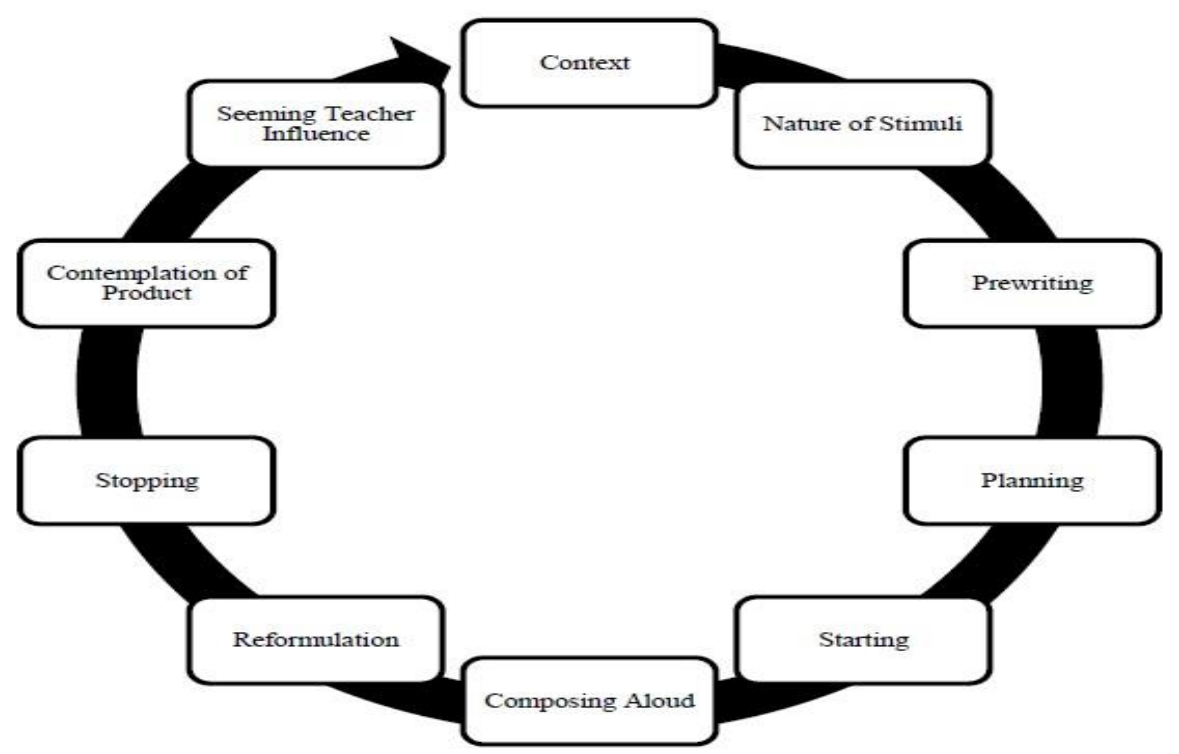

Figure 1: Emig's (1971) ten dimensions of the composing process 
Table 1: Summary of Emig's ten dimensions of the composing process

\begin{tabular}{ll}
\hline Dimension & \multicolumn{1}{c}{ Summary } \\
\hline Context of Composing & $\begin{array}{l}\text { Factors related to the community, family and schools that may } \\
\text { potentially influence the writer and their writing. }\end{array}$ \\
\hline Nature of Stimulus & $\begin{array}{l}\text { Stimuli that activate and maintain the writing process (e.g., self- } \\
\text { encountered or other-encountered stimuli and register). }\end{array}$ \\
\hline Prewriting & $\begin{array}{l}\text { The time during which a writer perceives the composition idea(s) } \\
\text { along with perceptions of the act of composing these idea(s). }\end{array}$ \\
\hline Planning & $\begin{array}{l}\text { All oral and written work that occurs once the act of writing } \\
\text { commences. }\end{array}$ \\
\hline Starting & $\begin{array}{l}\text { The moment when the process of writing (i.e., writing on a paper) } \\
\text { actually begins. }\end{array}$ \\
\hline Composing Aloud & $\begin{array}{l}\text { The process when a writer externalizes the internal process of } \\
\text { composing. }\end{array}$ \\
\hline Reformulation & $\begin{array}{l}\text { Means the correcting, revising and rewriting a writer applies to their } \\
\text { writing. }\end{array}$ \\
\hline Stopping & $\begin{array}{l}\text { The moment when a writer stops the process of writing because they } \\
\text { reached the end of a draft, feels all possibilities for writing have } \\
\text { been reached or presents the writing for evaluation from others. }\end{array}$ \\
\hline Contemplation of & $\begin{array}{l}\text { The moment when a writer considers the quality and status of their } \\
\text { writing, especially with how readers will receive their written work. }\end{array}$ \\
\hline Seeming Teacher & $\begin{array}{l}\text { Influences on the writing that derive from the writer's practice, the } \\
\text { writer's statement, teachers' feedback from previous writings, the } \\
\text { Influence on Writing } \\
\text { instructional approaches of composition teachers during class. }\end{array}$ \\
\hline
\end{tabular}

\section{Donald M. Murray: Writing is an Experience of Ongoing Discovery}

Murray (1968) referred to the act of writing as a continuously evolving process: topics are rediscovered, more thorough understandings of the intended audience and their needs are developed, facts that may alter initially planned concepts are collected and ideas are organized in a manner that exposes gaps and reveals abundances with information. Murray emphasized that effective writing instruction requires students to be writers who engage with "a private discovery of writing problems and their solution" (p. 27).

Murray (1968) identified distinct stages that are present during the acts of writing (see Table 2). As shown in Table 2, a writer first discovers a topic for writing and develops a point of view about this topic. During this stage, a writer collects information about the topic in order to develop a thorough understanding. Murray identified the following as the twenty-one senses that a writer may use during this stage:

- the five senses (i.e., sight, hearing, touch, taste, smell);

- a sense of the specific;

- a sense of the general and

- a sense of people, skepticism, history, implication, problems, solutions, self, reader, involvement, detachment, curiosity, language, form and irony. 
In the next stage, a writer gains a sense of audience in order to gear their writing to its intended readers, which, according to Murray, should include audiences beyond the writing teacher. Subsequently, a writer then turns his/her attention to the creation of specific details that "show, don't tell" (p. 43). Murray emphasized the importance of a writer identifying specific details for their own writing independently, rather than through teacher-led writing lessons. The next stage, called Create a Design, requires a writer to seek for order with their thoughts. During this stage, a writer must be familiar with various organizational structures for writing and develop their ability to write leads. Before a writer moves to the writing stage, they must know (a) what they wish to write, (b) to whom they intend to write and (c) how they wish to write it.

Table 2: Murray's stages of writing

\begin{tabular}{ll}
\hline Stage of Discovery & \multicolumn{1}{c}{ Attributes } \\
\hline Discover a Topic & $\begin{array}{l}\text { A writer (1) develops a point of view towards the topic, (2) collects } \\
\text { information related to the topic, (3) identifies an appropriate form for the } \\
\text { topic and (4) advances development of the topic through a variety of senses. }\end{array}$ \\
\hline $\begin{array}{l}\text { Gain a Sense of } \\
\text { Audience }\end{array}$ & $\begin{array}{l}\text { A writer writes for others and conveys ideas through writing intended for a } \\
\text { reader. }\end{array}$ \\
\hline $\begin{array}{l}\text { Search for } \\
\text { Specifics }\end{array}$ & $\begin{array}{l}\text { A writer "shows" the reader with facts and ideas, rather than "tells" the } \\
\text { reader with words. }\end{array}$ \\
\hline Create a Design & $\begin{array}{l}\text { A writer seeks for order with their thoughts and creates an outline to } \\
\text { organize their ideas. }\end{array}$ \\
\hline Write & $\begin{array}{l}\text { A writer drafts ideas from their design while still discovering their topic. } \\
\text { Spelling, grammar and neatness and handwriting should not be critiqued in } \\
\text { the initial draft. }\end{array}$ \\
\hline Review Critically & $\begin{array}{l}\text { A writer makes thoughtful determinations about their writing, such as if the } \\
\text { conveyed message was the intended message. The writer should also receive } \\
\text { feedback from others. }\end{array}$ \\
\hline Rewrite \& Edit & The writer takes great care to ensure their written work is its best. \\
\hline
\end{tabular}

When a writer progresses to the writing stage, he/she uses his/her organizational design to draft their ideas (Murray, 1968). Although a writer uses this design to guide his/her writing, he/she continues to discover his/her topic while writing. Murray claimed that the most important part of this stage was meeting the deadline because a writer must develop "a habit of production" (p. 72). During the initial draft, a writer should not be concerned with spelling, grammar, and neatness with handwriting. Once the initial draft is complete, a writer reviews his/her writing critically and makes thoughtful determinations regarding whether the writing addresses the intended topic, is appropriate for the intended audience and if there are areas that require additional information. Murray recommended use of a peer review process as an effective way for a writer to give and receive feedback on his/her writing. Once the review of writing is complete, a writer rewrites and edits in order to make sure the writing is its best. Murray stressed that writers should not view this stage as a "punishment," but rather as a critical part of the writing experience.

\section{Robert Zoellner: A "Talk-Write" Model for Composing}

Zoellner (1969) asserted that a theoretical underpinning for composition was that written text represents thought. However, Zoellner argued that students are often asked to "think 
before they write," (p. 269) and called for a writing education that was incremental, transparent, individualized and mindful of writing as it occurs. He proposed a 'talkwrite' model for composing that transforms the act of composition within a classroom into both a social and public process. Zoellner emphasized that during the acts of writing, each student writer becomes a "model of the act of writing" (p. 310) for their peers. Thus, students are able to observe the processes involved with the acts of writing that normally take place inside the minds of different writers, along with reinforcement from the teacher of writing.

Zoellner (1969) defined four principles that are unique to the 'talk-write' model:

- The Principle of Intermodal Transfer assumes that students are more skilled with talking than writing. This principle also assumes that talk-write dialogue will facilitate intermodal transfer of skill from speaking to writing.

- The Principle of Intermodal Integration assumes that the continuous alternation of speaking and writing will reshape and bolster writers' voices with each skill set.

- The Principle of Sociovocal Reinforcement assumes that writing is a socially charged activity, not an isolated, private event.

- The Principle of Autogenetic Specification assumes that as students use to talk about their writing, they internally develop clear goals to improve their own writing.

Zoellner contended that while the 'talk-write' model is simplistic, it provides student writers with writing instruction that models actual processes during the acts of writing.

\section{John R. Hayes and Linda S. Flower: Three Major Processes of Writing}

Hayes and Flower (1980) proposed that proficient writers use three cognitive processes during the acts of writing: planning, translating and reviewing. Flower and Hayes (1981) asserted that this proposed model was built upon the following understandings: (a) the act of writing consists of distinctive thought processes through which a writer manages while writing; (b) these thought processes are structured in a tiered, embeddable manner; (c) writing is fueled by internally-developed goals and (d) writing goals are developed through the writer's purpose for writing, as well as insights that occur during the act of writing. Hayes and Flower $(1986,1987)$ later referred to these three processes as planning, sentence generation and revising and asserted that these processes were "heavily interwoven" and "may be applied recursively" (p. 1107). As writers progress through each process, they monitor their progress and determine when they should move to the next process (Flower \& Hayes, 1981).

As shown in Figure 2, Hayes and Flower (1980) identified planning as the first process during acts of writing. While engaged with planning, writers generate information from their long-term memory and the environment surrounding the writing task (i.e., the task environment). Writers also establish goals and organize a plan for writing that will guide the act of writing towards these goals. Once the process of planning is complete, writers progress to the process of translating. During this process, writers use reflective questioning to compose complete sentences, which enables writers to synthesize 
meaning with a form that expresses the intended meaning (Kaufer, Hayes \& Flower, 1987). Hayes and Flower (1980) assumed that information stored in long-term memory existed as "propositions" (p. 15). Therefore, writers must translate retrieved information into language suited for the writing task. Hayes and Flower identified reviewing as the final process during the acts of writing. While reviewing, writers read and edit their writing. They identify and correct errors with written conventions and imprecisions with meaning, as well as appraise how the composed text meets the writing goals established during planning.



Figure 2: Hayes and Flowers' (1980) proposed processes for acts of writing

Hayes (1996) later revised these cognitive processes during the acts of writing to text interpretation, reflection and text production. During text interpretation, writers create internal representations of information encountered through reading, listening and viewing graphic images. These internal representations transform into other internal representations during reflection as writers apply problem-solving, decision-making and inferencing skills. The last cognitive process, text production, works in conjunction with the task environment to transform the internal representations into written, verbal or graphic productions.

\section{Donald H. Graves: Process of Writing among First- and Third Students}

Vygotsky (1986) stated, "The evolution from the draft to the final copy reflects our mental processes" (p. 242) and promoted the importance of planning, drafting, and inner speech during acts of writing. Graves (1983, 1994) applied Vygotsky's paradigm towards the processes of writing and studied its effect on first- and third grade writers with Lucy McCormick Calkins and Susan Sowers. After observing these writers for three years, Graves identified two stages of distinct processes that were common among the young writers: beginnings and composing patterns (see Figure 3). Graves (1983) 
emphasized that that the processes within these stages were not a systematic order of actions. Rather, they encapsulated common actions that young writers took during acts of writing.

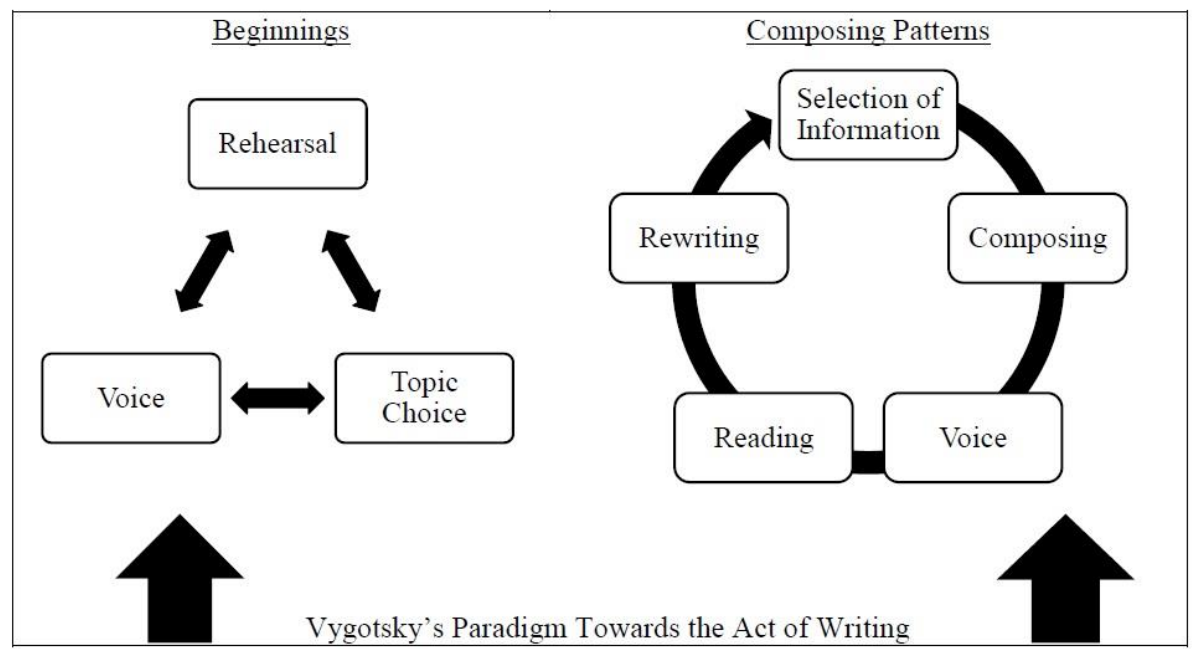

Figure 3: Graves's (1983) processes of writing

As young writers began writing tasks, Graves (1983) observed that they exhibited "Rehearsal" (p. 221) behaviors, which were sometimes unconscious to writers at first. However, once writers decided to write, Graves $(1983,1994)$ noted that rehearsals became conscious behaviors writers used to prepare for the acts of writing, such as imagining, doodling, drawing, making lists, charting, reading or engaging in dialogue with others. During the "Beginnings" stage of writing, writers also selected a topic and Graves (1983) noticed that the writers who engaged with writing more frequently were heightened.

Once writers began placing words on a paper, they were engaged with processes within the stage of "Composing Patterns" until all written drafts were completed (Graves, 1983, 1994). Graves (1983) acknowledged that while an overlap sometimes occurred between the stages of beginnings and composing patterns, the composing patterns stage essentially consisted of a select-compose-read-rewrite pattern. Graves also observed that each writer's attention to voice was present throughout the entire act of writing. Graves asserted that voice involved writer self-inquiring of “. . . what I want to say and how I want to say it" (p. 227).

\section{CONCLUSION}

Numerous other studies and additional literature have also described various processes involved with the acts of writing, including:

- Perl (1979) reported findings from a study conducted with five unskilled writers in college showing that each writer, although unskilled with writing, followed a sequential 
pattern of prewriting, writing and editing when composing. Perl's model mirrors aspects of existing models for writing (i.e., prewriting, writing and editing); however, her results showed that internalization of a process for writing existed even among the unskilled writers.

- Mayher, Lester, and Pradl (1983) pointed out discrepancies within the literature regarding the number of components involved during the acts of writing, as well as the relationships among cited components. Mayher et al. claimed that writers of all ages demonstrated the following common characteristics:

- percolating - any activity during writing that is apart from actual script on paper;

- drafting - the initial written expression;

- revising - the reformulation of ideas presented in the draft that is often guided by feedback;

- editing - the correction of errors with grammar and mechanics and

- publishing - the presentation of the completed written work.

- Langer (1986) analysed data produced from case studies conducted among 67 children regarding their reading and writing activities. Langer explored the children's independent use of reading and writing processes defined in the literature (i.e., generating ideas, formulating meaning, evaluating and revising) and found that the use of these processes while writing were complex and diverse, dependent on the age and difficulty of the task and different from how they were used during reading.

- Bereiter, Burtis, and Scardamalia (1988) presented findings that were supportive of their previously proposed knowledge-telling and knowledge-transforming models for composing. According to Berieter and Scardamalia (1987), knowledge-telling was merely a writer's retrieval of information from memory and rendering it directly into their composition. On the other hand, knowledge-transforming involves an element of reflection that accompanies information retrieval from memory. The use of reflection enables the writer to develop a new content using information from their memory using strategic thinking in how that information can be transformed to meet their goals to write more effectively.

It is clear from the literature that no definitive model exists for the processes writers use during the acts of writing. It is clear, however, that there are common processes among all writers. Bearing this in mind, Dyson and Freedman (2003) warned against creating a classroom environment that requires each writer to follow a mechanical pattern of planning, writing and revising because writers need flexibility during the acts of writing to engage with the various processes recursively. Therefore, in order to foster lifelong writing habits that are authentic and meaningful, it is necessary for teachers of writing to avoid prescriptive writing process models and to have a deep understanding of researchbased processes involved with the acts of writing.

It should be also noted that the Common Core State Standards do not demand the use of a specific process for writing. Teachers are "free to provide students with whatever tools and knowledge their professional judgment and experience identify as most helpful 
for meeting the goals set out in the Standards" (National Governors Association Center for Best Practices \& Council of Chief State School Officers [NGACBP \& CCSSO], 2010, para. 4). However, both Applebee and Langer (2009) and Hawkins and Razali (2012) ventured that the prominence of high-stakes testing will continue to drive the focus of writing instruction towards the end product, rather than on the processes involved during the acts of writing.

It is recommended that additional studies should be conducted with writers of all ages to explore the processes used during the acts of writing. With the availability of technology tools, composing processes may differ from those articulated in these six models. Furthermore, developing a research-based understanding of writers' processes used during the acts of writing allows for the identification of best practices with writing instruction.

\section{REFERENCES}

Applebee, A. N., \& Langer, J. A. (2009). What is happening in the teaching of writing?. English Journal, 98(5), 18-28. Retrieved from http://www.ncte.org/journals/ej/issues/v98-5

Applebee, A. N., \& Langer, J. A. (2011). A snapshot of writing instruction in middle schools and high schools. English Journal, 100(6), 14-27. Retrieved from http://www.ncte.org/journals/ej/issues/v100-6

Baines, L., Baines, C., Kunkel, A., \& Stanley, G. (1999). Losing the product in the process. English Journal, 88(5), 67-72. Retrieved from http://www.lawrencebaines.com/productprocess.pdf

Bereiter, C., Burtis, P. J., \& Scardamalia, M. (1988). Cognitive operations in constructing main points in written composition. Journal of Memory and Language, 27(3), 261-278. doi:10.1016/0749-596X(88)90054-X

Bereiter, C., \& Scardamalia, M. (1987). The psychology of written composition. Hillsdale, NJ: Lawrence Erlbaum Associates.

Dyson, A. H., \& Freedman, S. W. (2003). Writing. In J. Flood, D. Lapp, J. R. Squire, \& J. M. Jensen (Eds.), Handbook of research on teaching the English language arts $\left(2^{\text {nd }}\right.$ ed., pp. 967-992). Mahwah, NJ: Lawrence Erlbaum Associates.

Emig, J. (1967). On teaching composition: Some hypotheses as definitions. Research in The Teaching of English, 1(2), 127-135. Retrieved from http://files.eric.ed.gov/fulltext/ED022783.pdf

Emig, J. (1971). The composing processes of twelfth graders (Research Report No. 13). Urbana, IL: National Council of Teachers of English.

Emig, J. (1983). The web of meaning: Essays on writing, teaching, learning and thinking. Upper Montclair, NJ: Boynton/Cook Publishers, Inc.

Flower, L., \& Hayes, J. R. (1981). A cognitive process theory of writing. College Composition and Communication, 32(4), 365-387. 
Gillespie, A., Olinghouse, N. G., \& Graham, S. (2013). Fifth-grade students' knowledge about writing process and writing genres. Elementary School Journal, 113(4), 565-588. doi:10.1086/669938

Graham, S., McKeown, D., Kiuhara, S., \& Harris, K. R. (2012). A meta-analysis of writing instruction for students in the elementary grades. Journal of Educational Psychology, 104(4), 879-896. doi:10.1037/a0029185

Graham, S., \& Perin, D. (2007). A meta-analysis of writing instruction for adolescent students. Journal of Educational Psychology, 99(3), 445-476. doi:10.1037/00220663.99.3.445

Graham, S., \& Sandmel, K. (2011). The process writing approach: A meta-analysis. Journal of Educational Research, 104(6), 396-407. doi:10.1080/00220671.2010.488703

Graves, D. H. (1983). Writing: Teachers and children at work. Portsmouth, NH: Heinemann.

Graves, D. H. (1994). A fresh look at writing. Portsmouth, NH: Heinemann.

Grisham, D. L., \& Wolsey, T. (2011). Writing instruction for teacher candidates: Strengthening a weak curricular area. Literacy Research and Instruction, 50(4), 348-364. Retrieved from http://www.tandfonline.com/doi/pdf/10.1080/19388071.2010.532581

Hawkins, L. K., \& Razali, A. B. (2012). A tale of 3 P's - penmanship, product, and process: 100 years of elementary writing instruction. Language Arts, 89(5), 305-317. Retrieved from http://www.ncte.org/journals/la/issues/v89-5

Hayes, J. R. (1996). A new framework for understanding cognition and affect in writing. In C. M. Levy \& S. Ransdell (Eds.). The science of writing: Theories, methods, individual differences, and applications (pp. 1-27). Mahwah, NJ: Lawrence Erlbaum Associates.

Hayes, J. R., \& Flower, L. (1980). Identifying the organization of written processes. In L. W. Gregg, \& E. R. Steinberg (Eds.). Cognitive processes in writing (pp. 3-30). Hillsdale, NJ: Lawrence Erlbaum Associates.

Hayes, J. R., \& Flower, L. (1986). Writing research and the writer. American Psychologist, 41(10), 1106-1113. doi:10.1037/0003-066X.41.10.1106

Hayes, J. R., \& Flower, L. (1987). On the structure of the writing process. Topics in Language Disorders, 7(4), 19-30. doi:10.1097/00011363-198709000-00004

Kaufer, D. S., Hayes, J. R., \& Flower, L. (1987). Composing written sentences. Research in the Teaching of English, 20(2), 121-140. Retrieved from http://www.ncte.org/journals/rte

Lacina, J., \& Silva, C. (2011). Cases of successful literacy teachers. Los Angeles, CA: Sage.

Langer, J. A. (1986). Children reading and writing: Structures and strategies. Norwood, NJ: Ablex Publishing. 
Mayher, J. S., Lester, N., \& Pradl, G. M. (1983). Learning to write/Writing to Learn. Upper Montclair, NJ: Boynton/Cook Publishers.

Murray, D. M. (1968). A writer teaches writing: A practical method of teaching composition. Boston, MA: Houghton Mifflin Company.

Murray, D. M. (1985). A writer teaches writing $\left(2^{\text {nd }}\right.$ ed.). Boston, MA: Houghton Mifflin Company.

National Governors Association Center for Best Practices, \& Council of Chief State School Officers. (2010). Common Core State Standards: English Language Arts Standards - Introduction - Key Design Considerations. Retrieved from http://www.corestandards.org/ELA-Literacy/introduction/key-design-consideration/

Norman, K. A., \& Spencer, B. H. (2005). Our lives as writers: Examining preservice teachers' experiences and beliefs about the nature of writing and writing instruction. Teacher Education Quarterly, 32(1), 25-40. Retrieved from http://files.eric.ed.gov/fulltext/EJ795300.pdf

Perl, S. (1979). The composing processes of unskilled college writers. Research in the Teaching of English, 13(4), 317-336. Retrieved from http://www.ncte.org/journals/rte

Rohman, D.G., \& Wlecke, A. O. (1964). Pre-writing: The construction and application of models for concept formation in writing (Cooperative Research Project No. 2174). East Lansing, MI: Michigan State University.

Spear-Swerling, L., \& Zibulsky, J. (2014). Making time for literacy: Teacher knowledge and time allocation in instructional planning. Reading \& Writing, 27(8), 1353-1378. doi:10.1007/s11145-013-9491-y

Vygotsky, L. (1986). Thought and language. Cambridge, MA: The Massachusetts Institute of Technology.

Zoellner, R. (1969). Talk-Write: A behavioral pedagogy for composition. College English, 30(4), 267-320. doi:10.2307/374179

\section{Turkish Abstract}

Yazma Hareketleri: Yazma Sürecini Tanımlayan Altı Modelin Bileşimi

Yazma gelişimsel ve esnek bir süreçtir. Yazma hareketi için önerilen bir süreci kullanmak yazıcıların bireysel farklılıklarını dikkate almamakta ve dar, katı ve esnek olmayan bir yazma öğretimi oluşturmaktadır. Öğretmen adayları potansiyel olarak öğretmnelik mesleğini icra ederken yazma öğretiminde zayıf pedagojik uygulamalara neden olan sınırlı yazma teorisi ve pedagojisi almaktadırlar. Bu makalenin amacı yazma hareketinde geçerli olan süreçleri tanımlayan ve açılayan model tarihsel çalışmalar hakkında öğretmen eğitimcilerine, öğretmen adaylarına ve öğretmenlere temel bir bilgi vermektir.

Anahtar Kelimeler: yazma, yazma öğretimi, yazma modelleri, öğretmenler, yazma süreçleri

French Abstract

Les actes d'Écriture: une Compilation de Six Modèles qui Définissent les Processus d'Écriture

L'écriture est un processus lié au développement et flexible. L'utilisation d'un processus prescrit 
pour les actes(lois) d'écriture pendant l'instruction ne prend pas en compte les différences individuelles d'auteurs et produit l'instruction d'écriture qui est étroite, rigide et inflexible. Preservice des professeurs reçoivent la formation limitée avec la théorie et la pédagogie pour l'écriture, qui mène potentiellement aux pratiques pédagogiques faibles avec l'écriture de l'instruction parmi la réalisation de professeurs. Le but de cet article était de fournir, preservice des professeurs aux éducateurs de professeur et les professeurs pratiquants d'écriture avec une base de connaissance de recherche historique et les modèles qui définissent et décrivent des processus impliqués pendant les actes d'écriture.

Mots Clés: écriture, instruction d'écriture, les modèles d'écriture, professeurs, processus d'écriture

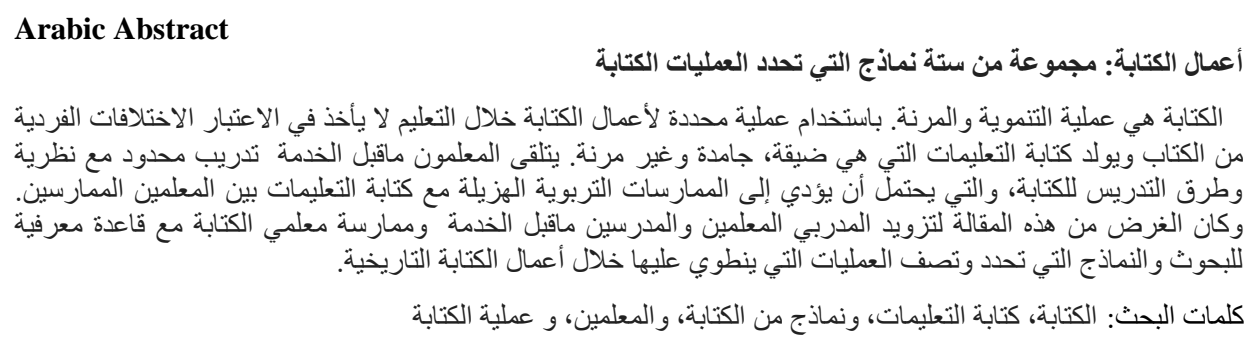

\section{German Abstract}

Handlungen des Schreibens: Eine Zusammenstellung von Sechs Modelle, Die Die Prozesse Des Schreibens Definieren

Schreiben ist ein Entwicklungs- und flexiblen Prozess. Wenn wir einen vorgeschriebenen Verfahren für die Handlungen des Schreibens während des Unterrichts verwendet nehmen wir keine Berücksichtigung der individuellen Unterschiede von Autoren und erzeugen Anweisung zu schreiben, die schmalen, starr, und unflexibel ist. Preservice Lehrer erhalten begrenzte Ausbildung mit Theorie und Pädagogik für das Schreiben, das pädagogische schlechte Praktiken führt möglicherweise mit Unterricht unter praktizierenden Lehrern zu schreiben. Der Zweck dieses Artikels war der Lehrerbildung, preservice Lehrer zu sorgen und zu üben Lehrer mit einer Wissensbasis der historischen Forschung und Modelle zu schreiben, die definieren und Prozesse in den Handlungen des Schreibens beteiligt beschreiben.

Schlüsselwörter: schreiben, anweisung $\mathrm{zu}$ schreiben, modelle des schreibens, lehrer, schreibprozess

\section{Malaysian Abstract \\ Tindakan Penulisan: Penyusunan EnamModel yang Menentukan Proses Penulisan}

Penulisan adalah satu proses perkembangan dan fleksibel. Menggunakan proses yang ditetapkan untuk tindakan penulisan semasa pengajaran tidak mengambil kira perbezaan individu penulis dan menjana penulisan arahan yang sempit, tegar, dan tidak fleksibel. Guru pra perkhidmatan menerima latihan yang terhad dalam teori dan pedagogi penulisan, yang berpotensi membawa kepada amalan pedagogi dan penulisan arahan yang lemah dalam kalangan guru-guru. Tujuan artikel ini adalah untuk menyediakan guru dan guru pra perkhidmatan berkaitan penulisan dengan berasaskan pengetahuan berlandaskan penyelidikan sejarah dan model yang menentukan dan menggambarkan proses yang terlibat semasa tindakan penulisan.

Kata Kunci: penulisan, arahan penulisan, model penulisan, guru, proses penulisan 